Short Communication

\section{CHANGES OF EIGHT METALS IN MOUSE TESTIS TREATED WITH CADIUM AND/OR SELENIUM}

$$
\begin{gathered}
\text { カドミウム就よ゙゙セレニウム同時投与 } \\
\text { マウスの精单での金属元溸の变動 }
\end{gathered}
$$

Key words: cadmium; selenium; calcium; magnesium; potassium; sodium; zinc; copper; iron; testis

In general, the cadmium (Cd) level in the testis is much lower than that in the kidney and liver in experimental animals exposed parenterally to $\mathrm{Cd} .{ }^{1)}$ However, $\mathrm{Cd}$ brings about a very rapid progression of changes in the testis, including irreversible depletion of testicular function accompanied by biochemical, $^{2)}$ histological $^{3)}$ or physiological ${ }^{4)}$ changes. Of these, the reduction in $\mathrm{Zn}$ level has been well demonstrated ${ }^{5)}$ in relation to the important role of $\mathrm{Zn}$ in the spermatogenic epithelium and to the similarity of the physico-chemical characteristics of $\mathrm{Cd}$ and $\mathrm{Zn}^{6}{ }^{6}$ However, very little is known about the changes of other metals in the testis induced by Cd exposure. We carried out experiments to clarify how eight kinds of metals, including $\mathrm{Zn}$, are influenced by $\mathrm{Cd}$ injection or simultaneous injection of Se and $\mathrm{Cd}$.

Materials and methods. Mature male mice (ICR, $5^{\prime}$ wk old) were kept at a constant room temperature $\left(25 \pm 0.4^{\circ} \mathrm{C}\right)$ and humidity $(42 \pm 5 \%)$ and were maintained on a controlled $12 \mathrm{~h}$ lightdark illumination cycle. Food (Type MF from Oriental Yeast Co., Ltd., Tokyo) and water were given ad libitum to the animals.

$\mathrm{Cd}\left(\mathrm{CdCl}_{2}\right)$ and/or $\mathrm{Se}\left(\mathrm{SeO}_{2}\right)$ were administered subcutaneously in deionized water every $24 \mathrm{~h}$ for 2 consecutive $\mathrm{d}$. The $\mathrm{Cd}$ group was injected with $\mathrm{Cd}$ at $0.012 \mathrm{mmol} / \mathrm{kg}$ and the Se group, Se at $0.024 \mathrm{mmol} / \mathrm{kg}$. The $\mathrm{Cd}+\mathrm{Se}$ group was given $\mathrm{Cd}$ and Se at the same time but at different sites. The control group was injected only with deionized water.

Blood and organs were obtained $3 \mathrm{~d}$ after the second administration. The right testis was fixed in $10 \%$ formaldehyde solution at pH 7.5 and stained with hematoxylin-eosin. The other testis, liver and kidney were treated for the measurement of metals by a method previously reported. ${ }^{6)}$ A flame (Model 208, Hitachi Corp., Tokyo) or flameless (Model 180-80, Hitachi) atomic absorption spectrophotometer was used. Phosphorus was measured by the method of Allen. ${ }^{8)}$

Results and discussion. In both groups treated with $\mathrm{Cd}, \mathrm{Cd}$ level of the testis was only $1 / 20$ to $1 / 10$ that of the kidney $(7.3 \pm 0.9 \mu \mathrm{g} / \mathrm{g}$ tissue and $8.8 \pm 1.5 \mu \mathrm{g} / \mathrm{g}$ in the $\mathrm{Cd}$ and $\mathrm{Cd}+\mathrm{Se}$ groups, respectively) and liver $(18.2 \pm 2.9 \mu \mathrm{g} / \mathrm{g}$ tissue and $13.4 \pm 1.3 \mu \mathrm{g} / \mathrm{g}$ in the $\mathrm{Cd}$ - and $\mathrm{Cd}+$ Se-groups, respectively) (Table 1), However, the $\mathrm{Cd}+\mathrm{Se}$ group showed a value twofold higher than the $\mathrm{Cd}$ group alone. This result agreed with that previously reported. ${ }^{9)}$

Testicular $\mathrm{Zn}$ was significantly decreased by injection of $\mathrm{Cd}$ alone (Table 1). With the simultaneous injection of $\mathrm{Se}, \mathrm{Zn}$ level was returned to the control level. Cu was not changed significantly by $\mathrm{Cd}$ injection. $\mathrm{Fe}$ was greatly increased by $\mathrm{Cd}$ injection. The increase of Fe may be due to the elevation of testicular blood volume, possibly attributable to hemoglobin-Fe."

Of all the elements measured here, Ca showed the highest rate of change following $\mathrm{Cd}$ treatment (Table 1), $\mathbf{P}$ was decreased rather than increased by this treatment, while $\mathrm{Mg}$ was decreased to half the level of the control by $\mathrm{Cd}$ injection alone. The changes in levels of two metals, $\mathrm{Ca}$ and $\mathrm{Mg}$, suggest that the integrity of the membrane, e.g., the mitochondrial membrane, was lost. With the simultaneous injection of Se, the levels of the above two metals were restored to the control levels.

In a related work, Takkar et al ${ }^{10)}$ reported previously that a single injection of $\mathrm{Cd}$ to rats caused progressively severe calcification of the tubules between 7 and $90 \mathrm{~d}$ after treatment and that concurrent administration of $\mathrm{Zn}$ and $\mathrm{Se}$ prevented $\mathrm{Cd}$-induced calcification of the tubules. Recently, Sajiki et $\mathrm{al}^{11)}$ reported that simultaneous injection of $\mathrm{Ca}$ antagonist, verapamil, with $\mathrm{Cd}$ partly improved $\mathrm{Ca}$ channel and then testicular injury. Stacey and Klaassen ${ }^{12)}$ showed that changes in Ca flux probably did not play an important role in $\mathrm{Cd}$ hepatotoxicity in in vitro systems. Under our experimental conditions, it is difficult to determine whether the changes of the two metals proceeded to testicular damage because of the severe and widespread interstitial and tubular damages (photo not shown).

$\mathrm{K}$ and $\mathrm{Na}$ were changed in a manner similar to $\mathrm{Ca}$ and $\mathrm{Mg}$ with depression of $\mathrm{K}$ and enhance- 
Table 1. Element concentration in testis.

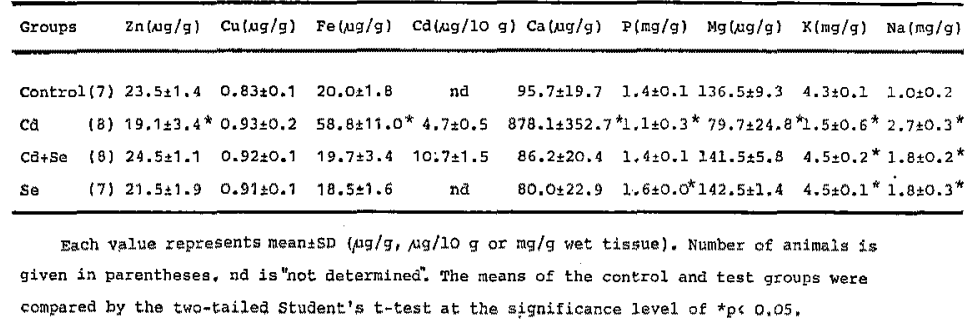

ment of Na (Table 1). Nechay and Saunder ${ }^{13}$ ) reported that $\mathrm{Cd}$ inhibited $\mathrm{Na}-\mathrm{K}$ ATPase in vitro. If this effect can be presumed to occur in vivo, the low activity of the Na-K pump may be due to conformation changes of this enzyme caused by the binding of $\mathrm{Cd}$. The effective action of Se on the normal regulation of $\mathrm{K}$ and $\mathrm{Na}$ may result from the improvement of testicular cell damage.

The changes of $\mathrm{Ca}-\mathrm{Mg}$ and $\mathrm{Na}-\mathrm{K}$ were not found in the liver and kidney. In both $\mathrm{Cd}$ and $\mathrm{Cd}+\mathrm{Se}$ groups, serum $\mathrm{Ca}$ and $\mathrm{P}$ were well regulated (data not shown). Serum $\mathrm{Cd}$ was $7.3 \pm$ $4.9 \times 10^{-3} \mu \mathrm{g} / \mathrm{ml}$ and $240.3 \pm 78.5 \times 10^{-3} \mu \mathrm{g} / \mathrm{ml}$ in the $\mathrm{Cd}$ and $\mathrm{Cd}+\mathrm{Se}$ groups, respectively. Gasiewicz and $\mathbf{S m i t h}^{14)}$ reported that with the simultaneous injection of $\mathrm{Cd}$ and $\mathrm{Se}$, each metal showed a high level when compared to that of a single injection of each metal. A certain serum complex bound specifically to $\mathrm{Cd}$ and $\mathrm{Se}$ seems to decrease the clearance of each element from the blood.

In conclusion, increases or decreases of $\mathrm{Ca}, \mathrm{Mg}$, $\mathrm{Na}, \mathrm{K}, \mathrm{Fe}$ and $\mathrm{Zn}$ were induced by $\mathrm{Cd}$ injection. Following simultaneous Se injection, the changed levels of metals were uniformly returned to the control level. The changes of the concentrations of these metals may be involved in the testicular dysfunction.

\section{REFERENCES}

1) Gunn SA, Gould TC, Anderson WAD. Selectivity of organ response to cadrnium injury and various protective measures. J Pathol Bact 1968; 96: 89-96.

2) Maekawa $K$, Tsunenari $Y$, Nobuki $K$, Waki $M$. The earliest effect of cadmium on the testis; an increase of alkaline phosphatase activity in the capillary wall of the testicular interstitium. Acta Anat Nippon 1965; 40: 200-208. (in Japanese)

3) Gunn SA, Gould TC, Anderson WAD. Zinc protection against cadmium injury to rat testis. Arch Pathol 1961; 71: 274-281.
4) Waites GMH, Setchell BP. Changes in blood flow and vascular permeability of the testis, epididymis and accessory reproductive organs of the rat after the administration of cadmium chloride. J Endocrinol 1966; 34: 329-342.

5) Gunn SA, Gould TC, Anderson WAD. Zinc in rat testis. Arch Pathol 1963; 75: 21-27.

6) Parizek J. The destrictive effect of cadmium ion on testicular tissue and its prevention by zinc. J Endocrinol 1957; 15: 56-63.

7) Sugawara N, Sugawara C. Selenium protection against testicular lipid peroxidation from cadmium. J Appl Biochem 1984; 6: 199-204.

8) Allen RJL. The estimation of phosphorus. Biochem J 1940; 34: 858-865.

9) Gunn SA, Gould TC, Anderson WAD. Mechanism of zinc, cysteine and selenium protection against cadmium-induced vascular injury to mouse testis. I Reprod Fert 1968; 15: 65-70.

10) Takkar GL, Chowdhury SR, Kar AB, Kamboj VP. Calcification of the seminiferous tubules of the rat testis after cadmium administration: prevention by zinc and selenium. Acta Biol Med Germ 1968; 20: $97-102$.

11) Sajiki J, Fukushima E, Fujishiro Y. Relationship between testes injury and calcium level in vivo in the rat administered $\mathrm{CdCl}_{2}, 11$ th Symp Environ Pollut Toxicol 1984; 137-139. (in Japanese)

12) Stacey NH, Klaassen CD. Lack of protection against chemically induced injury to isolated hepatocytes by omission of calcium from the incubation medium. J Toxicol Environ Health 1982; 9: 267276.

13) Nechay BR, Saunders JP. Inbibitory characteristics of cadmium, lead, and mercury in human sodium and potassium dependent adenosinetriphosphatase preparations. J Environ Pathol Toxicol 1978; 2: 283-290.

14) Gasiewicz TA, Snith JC. Interaction of cadmium and selenium in rat plasma in vitro. Biochim Biophys Acta 1976; 428: 113-122.

Naoki Sugawara and Chieko Sugawara

Department of Public Health, Sapporo Medical College, S.1, W-17, Sapparo, 060 Japan

管原直毅，菅原千枝子

札棍医科大学公得衛生学教室

Received for publication, April 28, 1986

Reprint requests to N. Sugawara, 通信先: 亘原 (值) あて 